\title{
Human Phenomenon in Philosophical Anthropology
}

Peter A. Ponomarev

Don State Technical University

\section{Natalia A. Zakharchenko}

Don State Technical University

\author{
Vadim P. Ponomarev \\ South Federal University \\ Email: ponomarev_p@mail.ru
}

\section{Doi:10.5901/mjss.2015.v6n3s1p544}

\section{Abstract}

This article discusses the basic concepts that define the nature and destiny of man, which took place in the development of philosophical thought. An overview of the characteristics of the person occupies an important place proposed by thinkers of Eastern philosophy and antiquity. Particular attention is paid to the cosmocentric concept that man is an integral part of cosmic unity and at the same time, thanks to the creative beginning, the universe converter. It is noted that in the Middle Ages religious understanding of human nature dominated. A man was seen as a unity of spirit, body and soul. Important in this period was the discovery of man's inner world. In the Renaissance was approved a new understanding of man. It is considered as an active subject of external and internal - his own nature (mind, soul). The man himself determines his destiny in accordance with his will and desires.

Keywords: man, spirit, soul, spirituality, mind, space.

\section{Introduction}

Human is a unique creation of the Universe. All human culture was busy unraveling human mysteries.

From ancient times to the present days the question about the human being nature, its origin and destination, the place of man in the world and society is one of the major problems in the history of philosophy.

The early Greek poet, natural scientist, and philosopher Empedocles wrote that human always was, is and will be the most interesting phenomenon for people. Sages and philosophers of ancient cultures realized the difficulties in the understanding of the human phenomenon. They offered a range of different interpretations of the human essence (space interpretations, anthropocentric and others).

The leading method used in the article is system and historico-logical methods, analysis, synthesis, integration of certain theses in the theory.

\section{The Question of the Origin and Essence of Man In Ancient Eastern and Greek Philosophy}

The question of the essence of man in philosophy is the most difficult. There are different views to this item: the nature of human forms his mind (Descartes, Hegel), instincts (Nietzsche, Freud), an immanent contradiction to the human being (Fromm); spirit, encompassing the mind, emotions, and will (Scheler); social quality, rather than its abstract nature (Marx), and others. This article contains an analysis of approaches to understanding the essence of a man, which are in philosophical literature, from ancient times to the present.

In Ancient Oriental philosophy ideas about the origin and the essence of human were largely mythological. The world assimilated to a man, Associativity, hylozoism, animism and anthropocentrism were characteristic of this period. These philosophical doctrines considered recovery, spirituality and assimilation of nature to man. At the same time the man assimilated to the world.

In the first written sources of Ancient China such as "The Book of Changes" and Confucius's doctrine were 
comprehended specific characteristics of man. Confucius believed that to be man is to love people. He considered humanity is the essence is man. Reciprocity and love to others distinguished humans from other creatures.

Mencius (Meng-tzu) was Confucius's follower. Central to the philosophy of Mencius (Meng-tzu) was the belief that man is by nature good. His innate moral sense can be developed by cultivation or perverted by an unfavorable environment. According to Mencius, humans differ from other animals in that they have four hearts or incipient tendencies: The hearts of compassion, of shame, of courtesy and modesty, and of right and wrong (of wisdom). The Opponent of Confucianism Mozi (Mo-tzu) believed that the main difference between human and animal was in his ability to work.

According to the Taoism doctrine human has dual nature. The first beginning of man comes from Tao. It is true and natural. The second beginning is generated by human ego with all its inclinations, passions and delusions. This beginning is false and artificial. The real true nature of man must win false.

A sage man was an ethical ideal of Taoism. The main quality of such man was non-action that is non-resistance to what was destined by Tao (Ableev, S.R., 2002)

The Ancient Indian philosophy was focused on the contrast of the passing world of daily human existence and the original spiritual fundamental principle of life. In this philosophy human existence was considered as a combination of body, mind, intellect and soul (spirit).

In the Ancient Eastern philosophy man was regarded as a spiritual being. This philosophical thought defined specific features (mainly moral) that distinguished human from animal.

Installation on human adaptation to the environment and strict following to the way which was foreordained by higher was a social orientation of human. The highest human goal is 10 achieve the liberation of consciousness. It gives awareness that true spiritual human "I" is above the body, feelings, mind, happiness and unhappiness, personal ego, space, time and the physical world. It is the consciousness of itself as the Absolute Spirit rising above change, suffering, evil and death [1. p. 40].

Thus, the most important feature of the Ancient Eastern philosophy of man was personality orientation on respectful and humane treatment both the social and the natural world. This philosophical tradition was focused on the improvement of man's inner world. Man defines the ways of improvement by himself and he is God and savior.

In the Ancient period were identified the most essential characteristics of man such as naturalness, rationality and sociality. They were considered from different positions (cosmocentric position (Democritus), logocentric position (Socrates), sociocentric position (Aristotle), anthropocentric position (Protagoras)). These concepts provided complexity and completeness in development knowledge about man. Sophists of Ancient Greece suggested anthropocentric interpretation of human essence ("man is the measure of all things" [Protagoras]). Protagoras emphasized that man was the main character of being. Knowledge, values, laws and customs are relative and must be commensurable with man.

Socrates was the first philosopher, who dedicated the central place in his doctrine thinking about man and sense of his existence, features of human nature. Socrates considered the soul as the essence of man. First of all he understood the soul as a unity of mind and moral.

Plato believed that human was composed of two parts: the soul and the body. The soul is the substance that makes us people. The soul is immortal unlike the mortal body. It can pass from one body to another.

General characteristics of man, his mission and social status depend on quality of the soul. According to Plato the eternal tragedy of human existence is unity and contrast of the soul and the body. Physicality puts human in the animal world, the soul elevates him above the world.

Aristotle was the first who defined human essence through his social qualities. According to Aristotle human is a social animal having mind. Sociality and intelligence distinguishes human from animal.

Aristotle formulated the idea of active human essence. He wrote that virtuous life of man has manifestation in activity and gives the only possibility for self-realization.

In Ancient philosophy cosmocentric concept dominated in the question of human essence. It was stated by Democritus. He understood human as "'small space" (microcosm) which was analog of big Space (macrocosm) or the Universe. According to Democritus human was a part of nature and consisted of atoms as the nature. Democritus regarded the soul as composed of one kind of atom, too. Death of the body leads to the destruction of the soul.

\section{Russian Philosophers-Cosmists about Cosmic Nature of Man}

Russian philosophers cosmists made a great contribution to the study of the cosmic human nature among them $\mathrm{V}$. I. Vernadsky, K. G. Tsiolkovsky, A. P. Chizhevsky, V. S. Solovyov, N. A. Berdyaev and others.

The deep and unbreakable relationship of human with the Space and the Earth with the Universe was typical for 
their concepts. They considered these problems from position of moral and spirituality. The central place in the doctrine of cosmists occupied the problem of overcoming evil in the space scale. It was the ethical orientation of this doctrine.

According to philosophers cosmists human is the organic part of the space unity and the universe converter thanks to his creative beginning. In the outlook of philosophers cosmists human considered as substance which contained the essence of the Universe and was the mam value of the creation. Russian philosophers thought that the purpose and the meaning of human life were his constant spiritual development and improvement. They believed that merge of humanity with the Space was possible if there was the development of the new spas\# consciousness and human spirituality. Philosophers cosmists stated that humanity actively- influenced the space processes and became the leading planetary and spate force. This state was new in science.

Thus, philosophers cosmists insisted on active and transformative mission of human in the Space. Spirituality of man was considered as the universal principle of human existence. The cosmists saw the supreme meaning of spirituality in activity for the benefit of man and in the creation of conditions for actualization of his creative abilities. They understood spirituality as the richness of human inner world and the cosmic expression of his soul. The main role in human life they gave to spirituality. High human spirituality was the source of the harmonious society. At the same time low human spirituality was the source of people's social troubles.

French naturalist and philosopher P. Teihard de Chardin (1881-1955) and Russian scientist V. I. Vernadsky developed the idea about possible achievement of the social and natural harmony. This idea was contained in the concept of noosphere. The essence of the concept was the special place of human in the universe. P. Teihard de Chardin and V. I. Vernadsky thought that human must consciously continue the evolutionary process because he was the perfect result of the organic world evolution. Human creates a special sphere (noosphere) or a sphere of mind that is the final stage in the Biosphere development. Thus, humanity becomes responsible for the course and the further evolutionary development of nature. A new level of harmony between the nature and the society assumes rejection from the utilitarian and transformative activity and transition to the lovingly transforming actions that meet the requirements of beauty.

Transforming nature human must approve spirituality counteracting the evil. Spiritual perfection of man is possible only in course of joining to the collective consciousness, in process of active attitude to life and the development of creative abilities.

Nowadays there are two main approaches on the human mission in the Universe. Representatives of the first approach believe that the human mission in the Space is to "'fit the society development in the natural environment most organically. Balance between the society and the nature should be reached by minimization of negative consequences of human converting activity.

Representatives of the second approach consider that human can change and improve nature actively. They think the human mission is to help nature to remove its imperfections and inconsistencies, to contribute the growth of its diversity and harmony (Shapovalov, V.F., 2004).

Thus, the human mission towards nature and the Space is an active work on creation a new level of the Space harmony on condition of responsible and caring human attitude to nature.

In modern scientific and philosophical literature are approved the ideas of the planetary and cosmic dimension of the human essence and the comparability of the human phenomenon with the phenomenon of the Universe.

\section{Understanding of Man's Essence in the Middle Ages and in the Renaissance}

In the Middle Ages the Holy Scripture had a great influence on the formation of ideas about human. In this period dominates theocentric understanding of human. Human being appeared as God's creation. His main mission was communion with God and salvation on the Day of Judgment.

The basis of religious understanding was the creationist approach according to it human had the triad essence. There are different religious interpretations of the human essence (Buddhist, Islamic and Christian). We will consider the religious concept of human in Christianity.

According to Orthodox anthropology human consists of three parts: the spirit, the body, the soul. The body is a material part of human. The soul is a human vital force. It communicates with the outside world and reacts to various facts and events of reality. The soul controls the body. I he spirit is the image of God in human. It dominates over the body and the soul. The spirit acts as a judge and gives the highest valuation to everything. The soul is created by the spirit. The spirit is eternal and uncreated. Unlike the soul it is perfect and unlimited.

Human occupies a unique place in the world thanks to the immortal soul. The life meaning of the believer is the soul salvation. For the soul salvation is necessary to follow Christ's precepts and to do good deeds for the benefit of 
people. "Bless are the merciful, for they shall obtain the mercy" [Matthew.5.7]. This precept of Jesus Christ did mercy the very important virtue of the Orthodox Christian. In the Orthodox doctrine was believed the merciful man approached God and established communications with him in the absolute sphere. Compassion and assistance to sufferers is the human care about the soul, the spiritual and moral perfection.

In the Orthodox tradition to be human is to realize the interconnection with the other people and the world in general. It means mutual responsibility having spiritual nature. Every Christian exists for another and both of them for God. Love for God and neighbor is the most important virtue. "Love your neighbor as yourself' [Matthew.22.29]. Love involves close connection with activity.

In Christian understanding human has spirituality since birth and it can develop during his life. The high degree of spirituality allows human to approach the Absolute. Christian anthropology gives human unlimited freedom to create his own essence and ability to form himself at his own will. The Christian doctrine says human being was created unlimited and infinite in his own image and likeness. Therefore, there is an idea about unlimited human possibilities and his infinite individual diversity. At the same time human is proclaimed passive participant of the divine order and he is miserable being in comparison with God.

Discovery of the human inner world (self-conscience) was made in this period and it was very important for philosophy. Aurelius Augustine (Blessed) made a great contribution to the development of this issue.

In the autobiographical concept "The Confession" Aurelius Augustine writes about the internal author's formation as a person. In this study there is a psychological introspection, a screening of the controversial nature of the personality development and an indication of the dark abysses of the soul. Representatives of the existentialism considered Augustine as their predecessor.

Thomas Aquinas believed human was an intermediate creature between animals and angels. He represented the unity of the body and the soul but the soul was "the engine of the body" and it defined the human essence. Unlike Augustine who thought the soul was independent from the body and identical to man. Thomas Aquinas considered human had personal unity of the soul and the body.

A new understanding of human occurred in the Renaissance. Firstly natural beginning was rehabilitated. Physical and sensual from sinful turned to natural and integral aspect of the human essence.

Secondly human place in the world and his destiny predefiniteness changed. Human determined the fate himself using his free will. He was the lord of his internal and external nature.

Thirdly there was the human deification. Philosophers of that time considered that human was a creature dominated over the natural and social world (Ableev, S.R., 2002). At the same time deistic and pantheistic concepts of human and the world creation replaced theocentric ideas. In this period humanistic idea was formed and it put human (not God) in the center of the universe.

\section{The Interpretation of the Essence of Man in Modern Times}

In New period of time mind was the human essence. Rene Descartes represented thinking as the only reliable evidence of human existence ("I think, therefore I exist"). This idea formed the basis of new European rationalism which in human mind and thinking saw specific tent tire of man, his essence. Thomas Hobbes believed the ability to argue, predict, summarize and formulate general rules distinguished human from animal. In other words it was ability to think.

In XVIII - XIX centuries logocentric idea was complemented by naturalistic and mechanical concepts. Naturalistic tendencies appeared in philosophical and anthropological views of French philosophers. Julien Offray de La Mettrie thought human was a machine, clockwork. P. Holbach in the treatise "The System of Nature" wrote that human was a natural unit. He could fell, think and act. Human was generated by nature and must obey its laws.

At the same time the great role was given to consciousness. Leibniz believed intellect distinguished human from animals. Intellect allowed human to know himself.

Representatives of German classical philosophy considered that human was a subject of the spiritual activity creating the world of culture and a universal carrier of the perfect beginning (spirit, mind).

"What is a person?" It was the main question of Immanuel Kant's philosophy. On the one hand human belonged to the natural necessity. On the other hand he had moral freedom and absolute values. As part of the sensual world human was subordinated to necessity but as consciousness carrier he was free. Kant assigned a leading part to the moral activity of human which should be based on principle of the categorical imperative. According to this idea every person was self-sufficient and shouldn't be considered as mean of problem implementation. Kant believed self-conscience was the main human difference from other creatures.

Hegel's anthropological concept was rationalistic. He wrote that thinking was the difference between human being 
and animal and it gave humanity to all mankind.

Hegel considered human was a subject of the spiritual activity and a carrier of the spirit and the mind.

In XIX century as opposed to naturalism began to arise sociologism. Its essence was the justification of priority social aspects of human existence. According to sociocentric concept the human nature was "a totality of social relations" (Marx). This Marx's statement meant the social relations through employment, training, education formed human qualities, his way of life. Human formed these relations himself; he actively changed the natural and social environment. Social relations included experience of human culture. Adapting to the world human created "the second nature" (culture). The general tendency of human dynamics was the development of the essential forces. Human socialized on the basis of mastering practical experience of human culture.

In the middle of the XIX century inationalistic views opposed the rationalistic interpretation of human.

In XIX - XX centuries various human concepts focused their attention on not thinking abilities (feeling, will, instincts and others). The problem of unconscious took an important place. Role and importance of mental processes were analyzed from different positions. There processes weren't realized by human. Freud had a great influence on the development of this problem. He thought unconscious was the most important factor of the human dimension and existence. Freudian person was full of contradictions between biological inclinations and social norms, conscious and unconscious, the life and death instinct. As a result biological unconscious was the main beginning in human life.

According to Freud human was an erotic being controlled by unconscious instincts.

Freud's followers developed and corrected his doctrine. They departed from the Orthodox Freud s concept. Increasingly they recognized the role of consciousness in human life and the influence of' social factors on the personality development. The Austrian psychiatrist Alfred Adler considered human was not only a biological being, but also social one. Human life activity was connected with conscious interests. Adler considered unconscious from a sociologism position. Thus, he tried to overcome the contradictions between unconscious and consciousness in human.

Arthur Schopenhauer was one of the first representatives of the philosophical anthropological irrationalism. According to his doctrine the world will was the basis of everything. Schopenhauer believed the world will was unconscious and it hadn't got aims...

In human the world will appeared as the "will to life" and the aspiration to satisfy desires and needs. However, such aspiration was the source of human suffering. Thus, in the world human was the slave of the will. Overcoming the "will to life" was the meaning of human life. Refusing himself in favor of others, feeling sufferings of another as own, sympathizing person was on the way of will to life denial. Only saints by full asceticism reached the complete denial of the "will to life".

This tradition was continued by Friedrich Nietzsche who was the founder of lite philosophy. He believed the basis of life was the will to power not the world will

According to Nietzsche human was determined by life forces libido not consciousness and mind. The idea of the "superman" occupied a very important place in the Nietzsche's concept. He considered the "superman" must have the will to power, the ability to rule and conquer. The "superman" must be free from all moral norms and recognize only one right (the right of the strongest). Distinctive features of the "superman" were the greatness of spirit, the height of ambitions and conscience. However, he was noble and respectful only among similar people. At the same time the "superman" didn't have love and compassion to weak people (Ableev, S.R., 2002). Thus, Nietzsche's "superman" was a God-man.

The existentialism proposed a new approach to understanding of human and his essential life tasks. This approach developed as an independent philosophical direction in XX century. The most well-known representatives of the existentialism were N. A. Berdyaev (1874-1948), L. N. Shestov (1866-1938), Martin Heidegger (1889-1976), Albert Camus (1913-1960), Jean Paul Sartre (1905-1980) and others.

According to existentialists' teaching existence preceded essence. At first human existed (lived, felt, suffered, thought, acted) and then he found essence. Human chose essence and life purpose himself. Albert Camus and Jean Paul Sartre believed human wasn't a set of any qualities he was a set of non-existent features which could be shown in the future. In their opinion was something unfinished having an opportunity for future development.

Life crises indicated human incompleteness. Human existence was a project, a sketch. Freedom was human fundamental characteristic. Man freely chose himself. He made this choice according to his values. The basis of the choice was freedom which depended on the subjective human intentions. Human couldn't (mustn't) aspire to the universal goals taking off his responsibility for actions.

According to Heidegger living in the world of care human didn't always become and remain person, he created individuality himself. Awareness of the death inevitability was able to return human qualities to people (Svinina, T.M., 2007).

In Russian religious philosophy the question of the human nature and essence was often considered from a 
position of dualism (physical and spiritual, freedom and necessity, good and evil, the divine and the earthly).

The idealistic religious interpretation human was represented by the Solovyov's doctrine. In his opinion human was a link between the divine and the natural worlds. On the way of love to God human as a spiritual being overcame evil and suffering. The vital human task was self- improvement, a union with God and an evil overcoming.

F. M. Dostoevsky had the irrationalistic approach to the problem of human. In his opinion human wasn't available to the rational explanation. He was center of existence and his main quality was freedom. The spiritual human rebirth was on the way of finding true freedom which was achieved by the liberation of human from passions. As a result he stopped to be a slave of himself and the environment. However finding of freedom was a hard way of trails and sufferings because freedom was irrational and could produce both good and evil.

The problem of the human soul and the body was reflected in the Berdyaev's doctrine. He thought "man was created in the image and the likeness of God. But at the same time human was natural and organic being. There was duality in the human being. Human was the intersection of two worlds, he reflected the highest and the lowest worlds... As a carnal being he was linked with all cycle of the world life; as a spiritual being human was connected with the spiritual world and God". Human fate was tragic in its essence because of this original duality and personal dualism.

In terms of the Russian religious philosophy the most important thing for human was spiritual, divine substance. The original meaning of human and his existence was connection with God. Man revealed the essence in God. God manifested in man.

\section{The Current Understanding of the Essence of Man}

In modern philosophical anthropology was fundamental the idea of the self-creating, opening for the further development and transcending personality. The human essence was in his spiritual sphere where there was a process of constant selfconstruction and self-education, spiritual perfection. Human was fundamentally incompleted being which was open for the world and was able to act and make choice.

The human nature was revealed through the concept of "I", "consciousness", "personality", and "spirit". The concept of "I" was opposed to any other reality and it allowed human to feel his existence. It became possible thanks to "consciousness" which gave clarity. Clarity was peculiar to "l". "Consciousness" separated "I" from the rest of reality. The concept of "personality" reflected the human autonomy. In this case "I" acted like conscious "I" making an independent choice freely and responsibly. Thus, personality had the strong-willed beginning.

These notions were parts of the spirit. Human was impossible without spiritual properties. The spirit transformed the life from the animal process in the human one, the reproduction and alternation of generations in the historical and cultural development (Shapovalov, V.F., 2000).

Lately in the Russian philosophy spirituality was considered as human essence. Spirituality was understood like set of gnoseological, moral, aesthetic, emotional and mental components (attitudes, motivation, etc.) of human inner world (Richkov, A.K., 2002).

It should be noted that non-religious authors restricted human essential characteristics by qualities which were shown in the empirical world.

Religious and esoteric literature focused on the human spiritual essence.

According to the integrated approach the spiritual essence could be found in work, communication and everyday consciousness. Thus, the spiritual and material essences were closely interconnected and interdependent.

In accordance with modern data human is a biological being which is generally related with other forms of life. He is a living system. This system is a unity of physical and spiritual, natural and social, genetic and acquired during the life. As a living organism human is included in the natural connection of phenomena and submits lo biological (biophysical, biochemical, physiological) laws. At the level of the conscious psyche and the personality human is facing to the social life with its specific laws.

Having speech, thinking, consciousness and sell- consciousness, moral and aesthetic qualities human is the subject of the historical process and the development of the material and spiritual culture.

The fundamental human qualities are his absolute value, integrity, uniqueness and universality. The human uniqueness is found in incompleteness of physical and spiritual development and in his unique natural inclinations and social properties, openness to the world, ability to work, communication and dialogue. The human universality is the ability to any kind of activity.

The person is the unity of three entities (natural, social and cultural). These entities determine his integrity.

As the biological being human is a set of natural, genetically determined properties developing in ontogenesis. Being the social creature human is a personality. He is a carrier of properties that determine his social nature, reflect both 
the specific social and economic relations and the history of society.

As the social being human has consciousness thanks to it he can reflect and transform the world. In this capacity human being acts as the subject of joint activity and communication and the carrier of social values, experience, norms, installations, culture and social roles.

Being the subject of social life human takes socially significant properties such as freedom, will, ability to create, creativity, dialogue and interaction, cooperation with other people. As the creative person and the subject of culture he has spirituality, cultural identity, tendency to search of the truth, goodness and beauty, self-awareness, capacity to reflection and self-improvement.

Each definite human has the property of uniqueness, originality and individuality.

Thus, we can distinguish three types of subjects:

1) The natural subject is a person who quickly adapts to changing environment conditions.

2) The social subject is a person as a carrier of social norms and rules.

3) The subject culture is a person who can solve live problems independently and responsibly on the basis of universal moral and cultural principles. (Stolyarenko, V.E., 2004)

One of the most important problems of anthropology is the problem of the biological and social relations. These relations aren't two parallel and independent from each other factors. They effect on human being simultaneously and comprehensively. Intensity and quality of the effects are different, they depend on many factors.

The biological and social development occurs during the human life. Morphological (height, weight, volume), biochemical (blood, bones, muscles), physiological (blood circulation, digestion) changes occur in the process of the biological evolution. The result of the evolution is human emergence as a biological species and a social creature. Being from birth exclusively a biological creature in the process of development human becomes a social being. He becomes a person as the subject of relations and social activity.

The fact that human is the historic, social and cultural being helps to understand his "nature". The human "nature" isn't set, each culture construct it in own way.

Transformation of the natural human in the social one is carried out during the familiarizing to the culture. Culture is an adaptive system which helps human to adapt to the environment. Synthesis of nature and society is inconceivable out of culture. Human self-control mechanisms are developed in the process of familiarizing to the culture. These mechanisms are expressed in the ability to regulate a wide range of inclinations, instincts using willpower this self-control is a social control. It suppresses impulses unacceptable for this social group and makes social conditions which necessary for life.

Biological and social role in the process of human development has different interpretation in the biological, sociological biosocial concepts.

The main provisions of the biological concept are:

- Human is a natural being.

- The spiritual personality traits have the biological basis.

- Development and behavior are determined by innate needs, drives and instincts and by external requirement to which human must adapt,

- Education can accelerate or slow down the process of natural development.

- In the sociological concept human development is interpreted as follows:

- Human is born as a biological creature but in the lite process he socialites under the environmental influence.

- Environment plays an important role in the personality formation.

- Education corrects environmental influence.

- Biological features (instinct of possession, destruction, sex and others) are weak it the level of personal development is high.

Supporters of the biosocial concept believe that:

- Human is a being both biological and social.

- Mental processes (thinking, imagination, memory and others) have biological nature.

- Orientation, interests, personality abilities are formed as a social phenomenon under the objective and specific factors influence of the social environment. (Pedagogy: textbook / edited by L.P. Krivshenlai., 2005).

Thus, studying the problem of human we can identify main philosophical approaches of different ideological orientation.

Theocentrism correlated human nature with the divine and fundamentally incomprehensible mystery.

Partocintrism considered human as a part of the Universe which had intellect.

Anthropocentrists believed human was the highest creation in the Universe being the supreme value. 
According to sociocentrists concepts society played a very important role in the human formation.

\section{Conclusion}

We considered the basis concepts and found human specifics (qualities which are human in the man).

Spirituality is a specific human quality; it characterizes the valuable and semantic sphere of the human inner world and determines the social, humanitarian and altruistic orientation of life activity. According to Kant moral plays a very important role, it rises human over the natural world and gives chance to distinguish good and evil. Being in the center of spirituality and its social manifestation moral is a measure of spirituality, characteristic of its quality. Russian philosopher Vladimir Solovyov (1853-1990) identified three human qualities that were the essence of the human (shame, compassion, and reverence for the highest). These qualities allow to ashamed of the lowest natural manifestations, to bow before the holy and sublime, to compassionate not only to man but every living being.

Summing up the results of the historical and philosophical analysis of human problem it is possible to do the following conclusions:

1. Study of the human phenomenon was an actual problem in the history of humanity and it generated many concepts.

2. As open to the world integrity human includes different components such as natural level (biological), spiritual level, social level (public), genetic level (universal) and space level.

3. Being a natural creature from birth becomes a social one in the process of acculturation.

4. Human is the only creature having reflexive consciousness. It can go beyond the limits, spiritually transform itself, be engaged in the introspection, self - construction, self-education.

5. The active mode of existence is typical for human. Work and joint activity played an important role in the human formation.

6. Spirituality is the deepest human essence. Shame, conscience, compassion, worship of nature and life are main human qualities.

7. Human being has such fundamental qualities as integrity, absolute value, uniqueness and universality.

\section{References}

Ableev, S.R., 2002 The history of world philosophy: textbook / S.R. Ableev. Moscow: Ltd "AST PUBLISHING HOUSE": "ASTREL PUBLISHING HOUSE". pp 416.

Shapovalov, V.F., 2004. Philosophy of Science and Technology; about the sense of science and technology, and global threats to the scientific and technological era: tutorial/ V.F. Shapovalov. - Moscow: FAIR-PRHSS. pp 320.

Svinina, T.M., 2007. Man is a system of multi-level and ambiguous/ T.M.Svinina// Graduate students and applicants.

Shapovalov, V.F., 2000. Fundamentals of Philosophy. From classic to contemporary: tutorial / V.F. Shapovalov. - The $2^{\text {nd }}$ edition, revised. - Moscow: FAIR-PRESS. pp. 608.

Richkov, A.K., 2002. Philosophy: tutorial for universities / A.K. Richkov. B.L. Yashin. - Moscow: Humanities Publishing Center VLADOS. pp 384.

Stolyarenko, V.E., 2004. Anthropology is a systemic science of man: tutorial for universities/ V.E. Stolyarenko, L.D. Stolyarenko. The $2^{\text {nd }}$ edition revised and enlarged. - Rostov- on-Don: Feniks. pp 384.

Pedagogy: textbook / edited by L.P. Krivshenlai., 2005. Moscow: PROSPECT PUBLISHING HOUSE. pp 432. 